5. Петров В. Концерт для кларнета с оркестром Моцарта. Методика обучения игре на духовых инструментах. Вып.4. М.: Музыка, 1976. С.157-187.

\title{
References
}

1. Bermann K. (1894). The manual of the clarinet. Translation of F. Zimmermann and S. Rozanov theoretical part of school for clarinet. Smolensk. [in Russian]

2. Burkackiy Z. (2000). About base technology finger of the clarinetist. The Scientific herald. The Music art and culture. Iss. 1. Odessa. P.330-337 [in Ukrainian]

3. Dikov B. (1983) Methods of teaching to play on klarnete. Moscow, Gosmuzizdat [in Russian]

4. Mulberg K. (1978). Study some component technology of clarinetist: The diss. of candidate of Arts according, spec.17.00.03 - musical art, Moscow: Gnesins GMPI [in Russian]

5. Petrov V. (1976). Concerto for clarinet with orchestra of Mozart. Methods of teaching to play on windinstruments. Iss.4. Moscow, Muzyka. P.157-187. [in Russian]

Стаття надійшла до редакції 09.04.2018 p.

UDC 78(09)(477.51)

\author{
Vasiuta Oleg \\ Ph.D. in Art Studies, Associate Professor, \\ Associate Professor of the Department of Arts \\ in the National University "Chernihiv Collegium" \\ named after T.G. Shevchenko \\ ORCID https://orcid.org/0000-0002-0217-3090 \\ robota-internet@ukr.net
}

\section{CHERNIHIV REVUTSKY MUSIC COLLEGE: EUROPEAN VECTOR OF DEVELOPMENT}

Purpose of the research. The research is related to the coverage of the process of accumulating the musical pedagogical experience of the Chernigov region, which corresponds to the historical traditions of European professional art education and becomes the basis of innovative developments at the present stage of its development. The research methodology assumes the following scientific approaches: historical-musical and comparative, which contribute to a comprehension of the continuum in the historical and artistic process of interaction of the all-European and domestic traditions of art education in their regional dimension; communicative and interdisciplinary allow us to characterize the specifics of individual musical specialties and the expediency of using its results in the modern educational process. The scientific novelty of the work consists in revealing the features of the historical process of accumulating the musical and pedagogical experience of the Chernigov region, in which the diversification and correlation of musical and educational work become fundamental factors in the formation of the pedagogy of the arts, consistent with the trends of European art education. Conclusions. The historical experience of artistic education in Chernigov testifies to the permanence of the national system of musical education, creates professional conditions for the adaptation of its components to the European educational space. The application of the historical and musical approach in the evaluation of educational pedagogical experience will be facilitated by the further extrapolation of his professional thesaurus into the pedagogical plane, becomes the fundamental basis of innovative developments in the contemporary stage of improving art education, fills it with an inner content and concepts that are in tune with the current ideas of the European vector of social development of the state.

Keywords: process, musical-pedagogical experience, integration, diversification, correlation, continuum.

Васюта Олег Павлович, кандидат мистецтвознавства, доцент кафредри мистецьких дисциплін Національного університету «Чернігівський колегіум» імені Т.Г. Шевченка

Чернігівський музичний коледж ім. Л.М. Ревуцького: європейський вектор розвитку

Мета роботи. Дослідження пов'язане з висвітленням процесу накопичення музичного педагогічного досвіду Чернігівським музичним коледжем ім. Л.М. Ревуцького, що відповідає історичним традиціям європейської фахової мистецької освіти і стає основою інноваційних напрацювань на сучасному етапі розвитку. Методологія дослідження передбачає використання історико-музикологічного, компаративного, комунікативноміждисциплінарного методів, що дозволяє охарактеризувати особливості становлення окремих музичних спеціальностей та доцільність використання результатів у навчально-виховному процесі. Наукова новизна роботи полягає в розкритті історичного процесу накопичення музично-педагогічного досвіду, в якому диверсифікація і кореляція фахової роботи стає принциповим чинником формування педагогіки мистецтв навчального закладу, що відповідає тенденціям європейської мистецької освіти. Висновки. Історичний досвід мистецької освіти Чернігівщини засвідчує сталість вітчизняної системи музичного виховання. Сприятиме подальшій екстраполяції фахового тезаурусу в педагогічну площину і стає принциповою основою інноваційних напрацювань сучасного етапу вдосконалення мистецької освіти музичним коледжем. Наповнює ії̈ внутрішнім змістом, поняттями, співзвучними актуальним ідеям європейського вектору суспільного розвитку держави.

Ключові слова: процес, музично-педагогічний досвід, інтеграція, диверсифікація, кореляція, континуум.

Васюта Олег Павлович, кандидат искусствоведения, доцент кафредры художественных дисциплин Национального университета «Черниговский коллегиум» им. Т.Г. Шевченка

(C) Vasiuta O., 2018 
Черниговский музыкальный колледж им. Л.Н. Ревуцкого: европейский вектор развития

Цель работы. Исследование связано с освещением процесса накопления музыкального педагогического опыта Черниговским музыкальным колледжем им. Л.Н. Ревуцкого, что соответствует историческим традициям европейского профессионального художественного образования и становится основой инновационных наработок на современном этапе развития. Методология исследования предполагает использование историкомузыкологического, компаративного, коммуникативно-междисциплинарного методов, которые способствуют осмыслению континуума историко-художественного процесса взаимодействия общеевропейских и отечественных традиций художественного образования. Характеризуют специфику отдельных музыкальных специальностей и целесообразность задействования результатов в современный учебно-воспитательный процесс. Научная новизна работы заключается в раскрытии особенностей исторического процесса накопления музыкальнопедагогического опыта Черниговского музыкального колледжа им. Л.Н. Ревуцкого, где диверсификация и корреляция музыкально-воспитательной работы становятся принципиальными факторами формирования педагогики искусств. Отражает тенденции европейского художественного образования. Выводы. Исторический опыт художественного образования Черниговщины свидетельствует о постоянстве отечественной системы музыкального воспитания, создает профессиональные условия для адаптации ее составляющих в европейском образовательном пространстве. Способствует дальнейшей экстраполяции профессионального тезауруса в педагогическую плоскость. Становится принципиальной основой инновационных наработок современного этапа совершенствования художественного образования. Наполняет его внутренним содержанием, понятиями, созвучными актуальным идеям европейского вектора общественного развития государства.

Ключевые слова: процесс, музыкально-педагогический опыт, интеграция, диверсификация, корреляция, континуум.

Relevance of research. Stage of transition of Chernihiv region to the innovative development of artistic education coincides with the time of the state independence of Ukraine and covers the end of XX - the beginning of the XXI century (1991 - 2018). At this time there is an active formation of the modern level of artistic culture of the region, formation and development of the fundamental principles of the modern paradigms of artistic education, embodied in the results of educational and pedagogical, and musical and educational activities of the Chernihiv Revutskiy Music College (Director - Honored Worker of Arts of Ukraine V.Sukhoversky). This college has changed its status and name several times since the foundation (1904): private, state, communal. In the status of a Music College it has been operating since 2017 [17]. The work of this educational institutions during this period has a systematic character and covers educational and methodical, scientific and pedagogical, musical and performing spheres. The result of this work is aimed at achieving a sustainable perception of modern innovations of artistic education by a creative person (student or teachers), musical-pedagogical community of the region (the college performs the methodical work on professional music education at all levels of its implication), executive authorities, whose competence is the implication of the state policy to education. The principle position of an educational establishment promotes the formation of innovative visions realized by the stage-by-stage development of the musical-educational process, setting up a creative atmosphere that provides their introduction and has a predictable positive result.

The purpose of this study is to highlight the historical accumulation process of the artistic experience of professional musical education in Chernihiv Music College, which contributes to a successful solution of educational problems and covers a wide array of pedagogy of arts and supports a high level of college innovative culture and becomes the basis of its creative development. This innovation is based on the improvement of educational potential of the institution and involvement in the educational process of the development, covering the world and local professional experience of musical education as well as effective response to modern trends in artistic education with the next incarnation in educational practice on the basis of pedagogical correlation and diversification. Key determinants of innovative visions of the Music College, from our point of view, are a fruitful combination of the educational process of scientific and educationalmethodical components, support for an interfacial dialogue and creative cooperation. In this context, the scientific approach provides a predictable vision of musical-pedagogical purposes, revealing their effective mechanisms and their introduction into the educational practice, contributes to a sequential schedule and generalization of innovative development and provides productive creative functioning and interaction of various factors of artistic education. By its very nature, historical and musical approaches involved in the educational practice and educational process are the phenomena that promote the organic combination of the main goals of professional education, form a whole complex of educational activities aimed at training professionals, who meet European standards of artistic education. It facilitates the mobilization of the educational resource on solving the educational problems of Ukrainian society in the modern world.

The coverage of entry issues of Ukraine to the European process of artistic education can be found in works of our scientists, such as V. Roga [10], N. Gerasimova-Persian [5], O. Beregovoy [2], A. Lyagushchenko [6] and others. The artistic and scientific elite of Ukraine has got a positive experience that allows us to outline the ways of modernization and preservation of the best achievements of local artistic experience. In particular, the Academician of the National Academy of Arts of Ukraine V. Rozok emphasizes the preservation of the local "natural and vital structure of academic artistic education". At the beginning of the XXI century [10]. In addition, with the expansion of artistic educational services, the scientist says that it is necessary to move not towards the unification, but towards integration (italics by VR), while retaining its own work 
in the realm of artistic education, which is confirmed by a high-level, in particular by the graduates of the $\mathrm{Na}$ tional Music Academy of Ukraine. V. Roshch emphasizes: "The Ukrainian system of musical education has proven its historical value and has been recognized in Europe" [10].

A famous figure in the drama and choreographic culture of Ukraine A. Lyagushchenko reveals the main directions of local modern choreographic education, aimed at intensifying the process of educational practice which provides "... the preparation of a cross functional performer, who perfectly owns the techniques of classical and folk-stage dance and is acquainted with the latest choreographic techniques" [6]. A. Lyagushchenko emphasizes: "The philosophy of the educational process in the Academy is based on the principle of a continuous and graduate training of ballet artists, who provide the opportunity to solve common educational-creative tasks and issues" [6].

Presentation of basic materials. The foundation of the Chernihiv Music College (1904) became a turning point in shaping the professional foundations of musical education of the XX century. An example of the involvement of the European educational model has become the opera class headed by a well-known opera singer V. Grozdov-Dykovskaya. The teacher was actively involved into the educational process of the acquaintance with the European opera literature [8]. Among the many musical events of this period in Chernigov an Italian opera of a known entrepreneur N. Gonzalez made a difference (1907) [11]. In the history of the musical culture of the Chernihiv region it was the first performance of an opera troupe, based on its creative composition (orchestra, choir, soloists) relied on its own creative forces. It gave the opportunity of real dating and creative mastering the musical and creative specifics of the Italian vocal school. As it is known, the ethnolinguistics (linguistic ethnology) plays a leading role in the expansion of the sphere of musical and vocal performances, which forms the linguistic world of the vocalist-performer and becomes a reality of the musical-educational process [1, 263].

Tours of the Italian opera included the following works: J. Verdi - "Trubadur", "Traviata", "Aida"; Sh. Guno - "Faust"; J. Bizet - "Carmen", R. Leonkovallo - "Pyatitsy"; P. Mascagni - "Rural honor", which became an example of Italian vocal culture, an evidence of the achievements of the European vocal practice, which has found its expression in the general structure of the vocal art, the stage performance of an artist, the peculiarities of vocal sound formation, skillful usage of registers and timbre of voices (soprano, mezzo soprano, tenor, bass). In particular, in his own vocal guidance, a prominent Italian teacher-vocalist of the XIX century. F. Lamperti stressed: "The part must be studied not only by the throat, but also by the mind, as it is very important to keep the voice - the tool as fresh as possible for the theater", which the performances of the Italian opera have demonstrated to the full [9, 114].

A striking examples of the combination of the national and Western European opera literature were also the performances of the Society of St. Petersburg Opera artists directed by M. Shigaeva (1908) [14]. Repertory posters included the works of M. Glinka "Life for the Tsar", O. Dargomyzhsky "Mermaid", P. Tchaikovsky "Eugene Onegin" and "Peak Lady", J. Verdi" Traviata", Sh. Guuno" Faust" and R. Leonkovallo "Pyatitsy".

The mentioned association of opera artists in the implementation of stage performance relied on a creative concept based on professional principles of opera performance, which peculiar to the main creativity generators factors of the opera: orchestra, choir, soloists. This approach provided for the disclosure - the realization of creative potential opera ensemble in the sense of vocal-solo self-identification and artisticexecutive decision.

The activity of Chernihiv Music College has become a new stage in the further development of the musical-educational process and professionalization of various spheres of musical culture in the early 20 's. XX century [7]. By this time there was a significant deepening of pedagogical-professional principles for each of music specialties (opera singing, piano, violin, cello, wooden and brass wind instruments, the theory of music and compositions, etc.) and there was an expansion and complication of the structure of the educational process, the intensification of the process of special musical education: the performing, musicalpedagogical, theoretical (musical). Regulations of the statute of the musical school supposed to hold closed by each specialty musical evenings (academic concerts) each week, which contributed to familiarization with pedagogical methods and recorded student's achievement according to the program requirements. These requirements were necessary for each age groups of musical and performing culture. Conducting of an open public a concert by each class of the school was a prerequisite for the educational-educational process. In April - May there were open examinations, which ended with a musical evening (grand concert) with participations of choir, symphony orchestra and small chamber-instrumental performances. The structure of the educational process involved a close relationship of various subject-professional commissions (divisions). Each student received 30 minutes of special class per week. He attended classes on the theory of music, solfeggio, general piano. For all music specialties there was a compulsory participation in the student choir, various ensemble forms music making: duets, trio, quartets, quintets, sextettes, symphonic music orchestra (for musical instrumental specialties). The training course for all specialties had a worked-out professional-age correlation: preparatory, younger, middle, higher. The training plans were flexible to response to the individual and creative peculiarities of a student, which affected the term his stayed in each age group and stimulated search and application of various musical and pedagogical techniques. (Recall students from each specialty every Sunday publicly reported to the academy about the success of the studies). Everyone 
was preparing for the future practical music-professional activities. On this purpose, there was a substantive diversification-professional variation. For example, in the classroom, the total number of special disciplines, besides the general ones, were supplemented by a number of others narrow-profiled: general vocal-choral preparation, lyrical vocals, Italian language, professional vocal training, opera vocal preparation, opera, dramatization, declamation and stage reading. (Opera studio operated at the college on an ongoing basis). Similar approaches to the education of professional carriers of musical art had steady direction and gave positive practical results. So, the examples from the history of artistic education of Chernihiv region are convincingly presented. It proves that the process of targeted professional diversification and correlation contributed to the formation of a person capable of professional music and creative activities.

The scientific novelty of the work lies in uncovering the features of the historical process of accumulation of musical and pedagogical experience of the Chernigov musical college, in which diversification and correlation of musical education work become the principal factors in the formation of the corresponding pedagogy of arts trends in European artistic education.

Conclusions. The conducted research confirms historical continuity of European traditions of professional music education in domestic practice artistic education, which contributes to its adaptation to the European educational system. An increase in the regional musical-pedagogical experience has specific goals of the national practice of artistic education and provides:

- formation of an individual creative style of artistic educational institution that meets the contemporary requirements of artistic education and takes into account its own work and a wide range of professional factors that determine and form creative student's personality;

- creation of a system of educational and pedagogical work, which is based on the introduction of various techniques of artistic education based on their correlation, simulation and forecasting of learning outcomes;

- introduction of effective mechanisms of adaptation in the educational process of strategic development of the national music-professional education and revealing the ability to respond flexibly to trends in world art practice education;

- forecasting the results of educational work, formation personnel potential and educational standards that take into account peculiarities of each music specialty and meet long-term goals of educational process.

From our point of view, in the general system of national artistic education the following factors of its functioning are getting further development :

- through the vision of musical training - further introduction of multi-level artistic education on the basis of creation polyphonic artistic educational complexes in the following ways: "school - collegeacademy";

- the introduction of an artistic educational system that involves unity and interaction of various factors of professional music education: pedagogical, performing and scientific (educational) -methodological.

The conducted research confirms the historical significance of accumulation of musical-pedagogical experience and promotes the realization of the main goals -formation of personnel potential at the level of professional requirements of a sustainable society.

\section{תimepamypa}

1. Антонюк В. Етнолінгвістика в музичному вокально- виконавському мовленні // Виконавське музикознавство. Енциклопедичний довідник. К., 2010. С.263

2. Берегова О. Сучасні комунікаційні технології і фрормування творчої особистості // Наук. вісн. Національної музичної академії України імені П. І. Чайковського. Випуск 105. Збірник наукових статей, К., 2013. С. 103115

3. Васюта О. Музичне життя на Чернігівщині у XVIII - XIX ст. Чернігів: РВК «Деснянська правда», 1997.

212 c.

4. Васюта О. Співаки Чернігівщини . Чернігів, 2006. 101 с.

5. Герасимова-Персидська Н.О. Нові тенденції в українській музичній освіті: європейський контекст // Матеріали науково-практичної конференції «Музична освіта в Україні: сучасний стан, проблеми розвитку». К., 2001.C. $23-26$

6. Лягущенко А. Г. П'ятнадцять років навчання і творчості // Музика. 2017. № 2. С. 20-23

7. Ляшенко Т. Шляхи вдосконалення та професіоналізації Чернігівського музичного училища в першій третині XX століття //100 років Чернігівське музичне училище ім. Л.М. Ревуцького. Чернігів, 2004. С. 29-55.

8. Музикальное училище свободного художника К.В. Сорокина// Черниговское слово. 1907. 26 авг.

9. Назаренко И. К. Искусство пения: хрестоматия. М., 1963. С. 114.

10. Рожок В.І. Освіта і Болонський процес // Музика 2006. №1(січень, лютий). С. 18-20.

11. Театр и искусство. Итальянская опера // Черниговское слово.1907. 10 апреля

12. Театр и искусство. Итальянская опера // Черниговское слово.1907.11 апреля

13. Театр и искусство. Итальянская опера // Черниговское слово.1908.18 марта

14. Театр и искусство. Летний театр // Черниговское слово. 1908. 3 апреля

15. Театр и искусство. Летний театр // Черниговское слово.1908.1 апреля

16. Театр и искусство. Летний театр // Черниговское слово.1908. 28 марта 
17. Чернігівське музичне училище ім. Л. М. Ревуцького:провідний мистецький заклад, Інформація «КІЖ»// Культура і життя.2004.1 грудня.

\section{References}

1. Antonyuk V. Ethnolinguistics in a musical vocal performance speech // Performing Musicology. Encyclopedic reference book. K., 2010. p.263

2. Beregovaya A. Modern Communication Technologies and Personality Formation / Beregovaya A. // Nauk. Ros. National Music Academy of Ukraine named after P. I. Tchaikovsky. Issue 105. Collection of scientific articles, M., 2013.- P. 103-115

3. Vasiuta O. Musical life in the Chernihiv region in the XVIII - XIX centuries. Chernihiv: RVC "Desnyanskaya Pravda", 1997-212 p.

4. Vasiuta O. Singers of Chernihiv / Vasiuta O, - Chernihiv, 2006. 101 p.

5. Gerasimova-Persidskaya N.A. New Trends in Ukrainian Music Education: European Context / N.A. Persian // Materials of the scientific-practical conference "Music education in Ukraine: the current state, the problems of development." - K., 2001. P. 23-26 20-23.

6. Lyagushchenko A.G. Piatadtsyat years of study and creativity / AG Lyagushchenko // Music-2017. № 2.- S.

7. Lyashenko T. Ways of improvement and professionalization of the Chernigov Musical College in the first third of the twentieth century. / T. Lyashenko // 100 years of Chernigov Music School. L. Revutsky. - Chernigov, 2004. pp. 29-55.

8. Musical College of the free artist K.V. Sorokin // The Chernigov word. 1907. 26 sickles.

9. Nazarenko I.K. The art of singing: Reader. IK Nazarenko. -M., 1963. P. 114.

10. Rozhok W. Education and the Bologna Process / W. Rozhok // Music 2006 № 1 (January, February) .- P. 18-20.

11. Theater and art. The Italian opera // The Chernigov word.-1907.-10 April.

12. Theater and art. The Italian opera // The Chernigov word.-1907-11 April

13. Theater and art. The Italian opera // The Chernigov word.-1908-18 March

14. Theater and art. Summer Theater // Chernihiv word.-1908.- April 3

15. Theater and art. Summer Theater / / Chernihiv word.-1908.- April 1

16. Theater and art. Summer Theater // Chernihiv word.-1908.- March 28

17. Chernigiv Music School. L.N. Revutskiy: leading art institution, Information "KIZ" // Culture and Lives. In 2004 December 1.

Стаття надійшла до редакції 28.04.2018 p. 